\title{
Transfer Teknologi Budidaya Tanaman Hias untuk Guru-Guru Biologi
}

\author{
P.K. Dewi Hayati, Warnita, Netti Herawati, Sutoyo, Martinius, Trizelia, dan \\ Herviyanti \\ Fakultas Pertanian, Universitas Andalas, Kampus Limau Manis, Padang, 25163. Indonesia \\ E-mail: pkdewihayati@agr.unand.ac.id
}

Keywords: hybridization, ornamental crop, planting media, propagation, plant growth regulator

\begin{abstract}
Cultivation of ornamental plants in the school is necessary to provide the loveliness, and conductive atmosphere and environment for the learning process in that school. This community empowerment program aimed to transfer knowledge and technology of ornamental plants cultivation, covering the aspects of growing media, application of plant growth regulator, propagation and hybridization of ornamental plants to the biology teachers of high school. The methods of empowerment were community learning, demonstration, training, and self-practice. Results from the activities showed that the representative biology teachers from districts and cities in West Sumatra could be understood and applied the techniques of ornamental plants cultivation in their respective schools. The Likert analysis showed that a percentage of 95.6\%, indicating that the transfer of technology provided is very beneficial for high school biology teachers. Hence, this activity is needed to be continuous in the future.
\end{abstract}

\begin{abstract}
ABSTRAK
Penataan tanaman hias di lingkungan sekolah diperlukan untuk memberikan keindahan dan juga memberikan suasana serta lingkungan yang kondusif bagi proses pembelajaran di sekolah. Tujuan dari kegiatan pengabdian masyarakat ini adalah memberikan teknologi budidaya tanaman hias, meliputi aspek media tanam, aplikasi zat pengatur tumbuh (ZPT), perbanyakan dan persilangan pada tanaman hias, untuk guru-guru Biologi SMA. Metode pengabdian masyarakat yang digunakan meliputi penyuluhan, demonstrasi, pelatihan dan praktek mandiri. Melalui kegiatan ini, guru-guru yang merupakan perwakilan dari kabupaten dan kota di propinsi Sumatera Barat dapat memahami dan menerapkan teknik budidaya tanaman hias di sekolah masing-masing. Hasil evaluasi menggunakan analisis Likert memberikan nilai persentase sebesar 95.6\%, menunjukkan bahwa kegiatan pengabdian masyarakat yang dilakukan sangat bermanfaat bagi guru-guru Biologi SMA seSumatera Barat. Dengan demikian, kegiatan ini perlu dilanjutkan di masa mendatang.
\end{abstract}

\section{PENDAHULUAN}

Tanaman hias atau florikultur dikelompokkan sebagai tanaman hortikultura. Namun berbeda dengan tanaman sayuran dan buah-buahan yang juga tergolong tanaman hortikultura, tanaman hias dibudidayakan terutama untuk tujuan mendapatkan fungsi rohani atau dinikmati 
keindahannya (Zulkarnain, 2009). Hal ini berbeda dengan tanaman hortikultura sayuran atau buah-buahan yang budidayanya ditujukan terutama untuk mendapatkan fungsi nutrisi.

Penataan tanaman hias di lingkungan sekolah sangat penting tidak hanya untuk memberikan keindahan, namun juga memberikan suasana dan lingkungan yang kondusif bagi proses pembelajaran di sekolah. Beberapa sekolah bahkan mengalokasikan beberapa jam pada kegiatan ekstrakurikuler untuk melakukan budidaya tanaman hias. Tidak semua guru mendapat pembekalan atau pelatihan mengenai budidaya tanaman hias ini, sehingga kemudian guru-guru meminta agar Tim Pengabdi dari Fakultas Pertanian Universitas Andalas melakukan kegiatan pelatihan budidaya tanaman hias yang ditujukan untuk guru-guru biologi yang tergabung dalam Majelis Guru Mata Pelajaran (MGMP) Biologi SMA.

MGMP Biologi merupakan wadah bagi guru-guru yang memberikan mata pelajaran Biologi di SMA yang biasanya juga menjadi pengasuh mata pelajaran kewirausahaan budidaya tanaman hias. Budidaya tanaman hias merupakan pilihan budidaya tanaman yang paling banyak dilakukan di sekolah. MGMP Biologi dipilih dalam kegiatan ini sebagai mitra karena besarnya permintaan dan antusiasme dari guru-guru Biologi mengenai pembibitan dan pemeliharaan tanaman hias di sekolah. Apalagi jika sekolah tempat guru-guru tersebut menginginkan sekolahnya masuk sebagai sekolah adiwiyata.

Penampilan tanaman hias yang indah dan unik akan bernilai komersial tinggi. Beberapa teknologi seperti persilangan (hibridisasi) tanaman, teknik perbanyakan (propagasi) dan aplikasi zat pengatur tumbuh (ZPT) mampu menghasilkan perbanyakan tanaman secara cepat, penampilan yang lebih baik, unik, dan indah sehingga nilai jual tanaman hias menjadi lebih tinggi. Pemilihan jenis media dan komposisi media tanam sangat penting karena setiap tanaman hias membutuhkan persyaratan yang berbeda. Selanjutnya penampilan terbaik tanaman tentu juga perlu ditunjang dengan upaya pemeliharaan yang tepat. Pengetahuan mengenai pengendalian hama dan penyakit tanaman hias perlu diketahui agar tanaman selalu berada dalam performa atau penampilan terbaiknya.

Mitra pada kegiatan ini adalah guru-guru Biologi SMA. Beberapa permasalahan yang diidentifikasi dari observasi tim pengabdian Universitas Andalas adalah permasalahan pada aspek pengetahuan dan keterampilan para guru mengenai propagasi tanaman terutama teknik sambung (grafting), teknik hibridisasi dan pengendalian hama dan penyakit tanaman hias. Tujuan dari kegiatan pengabdian masyarakat ini adalah mentransfer beberapa teknologi budidaya tanaman hias, terutama aspek media tanam, penggunaan ZPT, propagasi tanaman, dan teknik hibridisasi kepada para guru-guru Biologi SMA se-Sumatera Barat.

\section{METODE}

Tahapan pelaksanaan kegiatan terdiri dari tahapan sosialisasi kepada ketua MGMP Biologi kota Padang dan Kepala Dinas Pendidikan Nasional propinsi Sumatera Barat, pelaksanaan kegiatan dari tanggal 29 April hingga 6 Mei 2017, dan evaluasi. Guru-guru mata pelajaran biologi yang mengikuti adalah 34 orang yang merupakan utusan dari kabupaten/kota se-Sumatera Barat.

Metode pengabdian transfer teknologi yang dilakukan meliputi penyuluhan melalui metode ceramah dan diskusi, demonstrasi, pelatihan dan praktek mandiri. Kegiatan berupa penyuluhan, demonstrasi dan pelatihan berlangsung pada hari Sabtu selama dua minggu berturut-turut. Tempat kegiatan berlangsung di Fakultas Pertanian Universitas Andalas. Penyuluhan dalam bentuk ceramah dan diskusi diberikan untuk topik tanaman hias, pembibitan dan perbanyakan tanaman hias, ZPT untuk induksi perakaran dan pengaturan pertumbuhan/perkembangan, serta hibridisasi tanaman hias. Demonstrasi dan pelatihan dilakukan bersamaan, masing-masing guru bekerja dan mempraktekkan apa yang disuluhkan pada beberapa tanaman. Praktek mandiri dilakukan selama satu minggu sebagai mana waktu yang telah disepakati sebelumnya dengan panduan modul Pelatihan Hibridisasi dan Propagasi Tanaman. 
Monitoring terhadap pelaksanaan kegiatan dilakukan selama kegiatan berlangsung. Evaluasi kegiatan dilakukan menggunakan metode survei yang hasilnya kemudian dianalisis secara statistik, baik menggunakan statistika deskriptif maupun menggunakan analisis Likert sebagaimana dilaporkan oleh Rusydi et al. (2015). Penilaian terhadap jawaban kuesioner diurut dari skor yang besar hingga kecil dimulai dari pilihan jawaban sangat bermanfaat, bermanfaat, biasa saja dan tidak bermanfaat.

\section{HASIL DAN PEMBAHASAN}

Kegiatan yang dilakukan pada awalnya merupakan permintaan dari guru-guru SMA yang mengajar mata pelajaran Biologi sehingga kegiatan diawali dengan sosialisasi kepada MGMP Biologi Sumatera Barat, Dinas Pendidikan propinsi Sumatera Barat dan pihak manajemen Fakultas Pertanian. Peserta kegiatan adalah utusan guru-guru Biologi SMA perwakilan kabupaten dan kota se Sumatera Barat.

Transfer teknologi budidaya tanaman hias dilakukan menggunakan beberapa metode meliputi penyuluhan, demonstrasi, pelatihan dan praktek mandiri. Kegiatan penyuluhan dilakukan dalam bentuk kuliah dengan memberikan porsi waktu lebih besar pada diskusi (Gambar 1). Kegiatan dilakukan selama dua hari. Materi yang diberikan terdiri atas topik pengenalan tanaman hias, pentingnya pengaturan jenis dan komposisi media tanam pada budidaya tanaman hias, serta pengendalian hama dan penyakit tanaman hias. Pemberian materi dilakukan oleh para dosen ahli di bidangnya masing-masing yang berasal dari tiga program studi yaitu Agroteknologi, Ilmu Tanah dan Proteksi Tanaman. Penglibatan berbagai bidang keahlian dan program studi bertujuan agar dapat memberikan pemahaman komprehensif mengenai tanaman hias, disamping menjadi wahana bagi para guru untuk lebih mengenalkan mereka kepada Fakultas Pertanian Universitas Andalas.
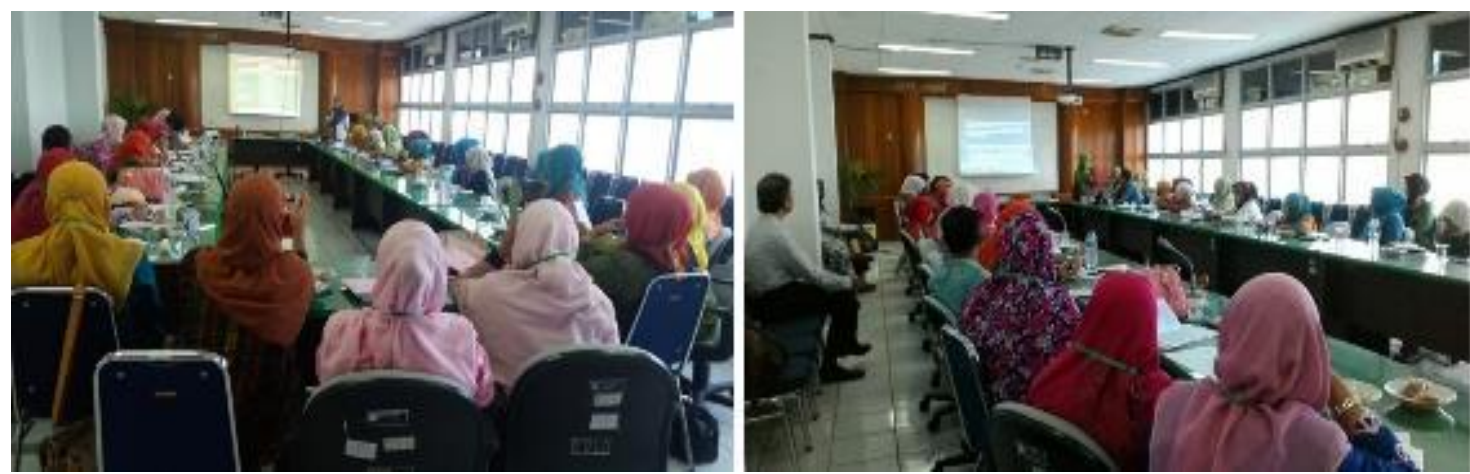

Gambar 1. Penyuluhan mengenai tanaman hias dan aspek budidayanya

Pembukaan materi penyuluhan dilakukan dengan mengenalkan fungsi tanaman hias yang walaupun tidak seperti tanaman pangan atau tanaman perkebunan yang mampu menghasilkan pangan dan devisa, tanaman hias melengkapi dengan memberikan fungsi keindahan. Tanaman hias juga berperan sebagai penyerap polutan, penyejuk dan penyegar, pemberi kenyamanan, peneduh, peredam suara dan silau serta sebagai pembatas tempat, memberikan nutrisi, berfungsi sebagai obat dan juga sebagai pestisida (Dewi-Hayati, et al., 2017a). Selain materi fungsi dan peranan tanaman hias, juga disuluhkan habitus tanaman hias dan syarat tumbuh dari berbagai tanaman hias seperti kebutuhan air, kelembaban dan cahaya.

Budidaya tanaman hias memerlukan pasokan hara baik yang bersumberkan bahan organik maupun non-organik agar diperoleh tanaman hias yang menarik sesuai dengan selera (Herviyanti, 2017). Media organik adalah media yang berasal dari komponen organisme hidup seperti sabut kelapa, pakis, sekam, humus, pupuk kandang, kompos, dan serbuk gergaji, sedangkan media non-organik adalah bahan dengan kandungan mineral tinggi yang berasal dari bahan induk di dalam bumi seperti pasir, kerikil, perlit, vermikulit, dan zeolit. Campuran media 
tanam yan merupakan komposisi dari berbagai media sangat disarankan sebagai media tanam untuk budidaya tanaman hias (Warnita et al., 2017).

Tanaman hias yang sehat akan menghasilkan performa yang baik dan menarik. Hal ini tidak terlepas dari upaya pengendalian hama dan penyakit yang menyerang tanaman hias. Hama yang paling banyak menyerang tanaman hias berasal dari golongan serangga. Pengendalian hama bisa dilakukan dengan cara membuang hama secara manual atau menggunakan pestisida (Trizelia et al., 2017).

Adapun penyakit yang menyerang tanaman hias terdiri atas penyakit fisiologis yang disebabkan oleh lingkungan seperti karena teknik budidaya yang salah, dan penyakit yang disebabkan oleh biotik seperti bakteri, virus dan jamur. Pengendalian penyakit infeksi terutama dilakukan dengan membuang sumber inokulum atau bagian tanaman yang sakit, sedangkan pengendalian penyakit fisiologi adalah dengan memenuhi kebutuhan fisiologis tanaman (Martinius et al., 2017).

Praktek mandiri dilakukan oleh guru bersama siswa di sekolah masing-masing selama satu minggu. Panduan praktek mandiri disediakan berupa modul dan disesuaikan dengan materi pelatihan yang telah diberikan sebelumnya. Praktek mandiri guru bersama siswa yang dilakukan adalah berupa identifikasi terhadap hama dan penyakit yang menyerang tanaman hias, dan praktek perbanyakan tanaman dengan teknik setek dan sambung (grafting). Selanjutnya masingmasing guru diminta untuk mengupload foto kegiatan yang dilakukan sebagai bukti kegiatan telah dipraktekkan sebagai syarat yang ditetapkan (Gambar 2).
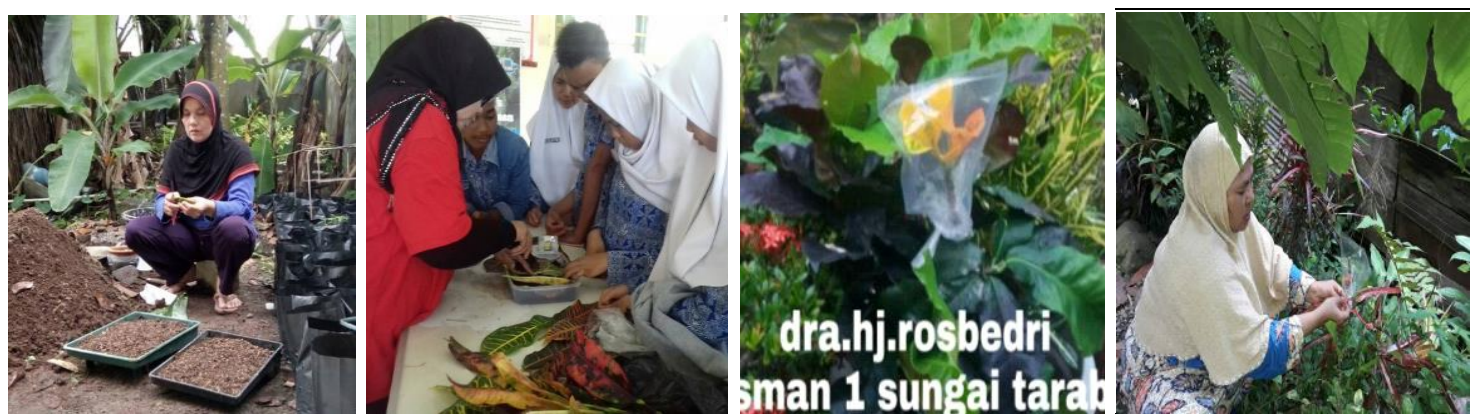

Gambar 2. Praktek mandiri yang dilakukan para guru di sekolah dan di rumah

Kegiatan demonstrasi dan pelatihan juga dilakukan selama dua hari sebagaimana kegiatan penyuluhan. Pelatihan meliputi pengaturan komposisi dan pembuatan media tanam pada pembibitan tanaman hias, berbagai metode propagasi tanaman, aplikasi ZPT dan teknik hibridisasi (Gambar 3). Berbagai tanaman seperti Sansevieria sp, Bougainville sp., Begonia sp., Aglaonema sp., Dieffenbachia sp., Calladium sp., Euphorbia milii, Adenium sp., Codiaeum sp., Excocaria cochinensis dan Dendrobium sp. disediakan sebagai objek propagasi buatan, hibridisasi dan aplikasi ZPT.
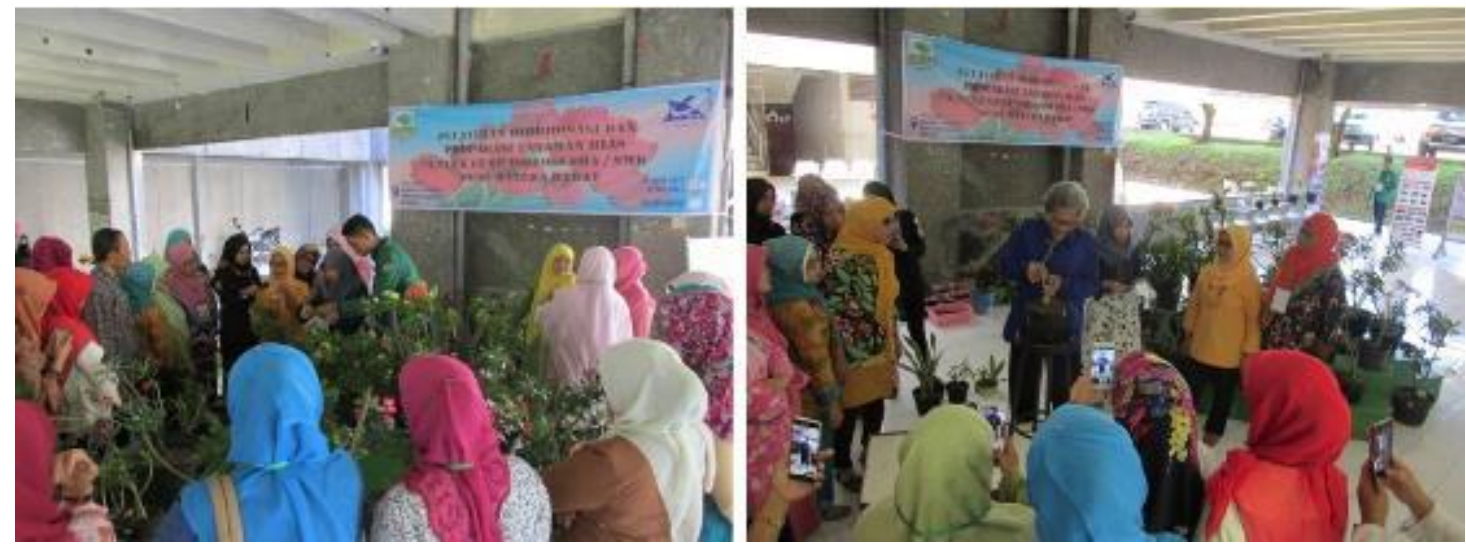

Gambar 3. Demonstrasi teknik perbanyakan dan persilangan tanaman oleh narasumber 
Penampilan tanaman hias yang indah dan baik bernilai komersial tinggi. Tanaman yang memiliki penampilan bunga yang unik dan menarik, bunga yang beragam dalam satu tanaman, pembungaan yang cepat, serempak dan banyak, keragaan tanaman yang kompak, pertumbuhan yang cepat dan mudah pemeliharaannya adalah beberapa kriteria yang digunakan untuk menentukan bagus tidaknya penampilan suatu tanaman hias.

Persilangan tanaman atau hibridisasi adalah salah satu teknik yang dilakukan untuk memperbaiki penampilan tanaman karena persilangan menggabungkan karakter-karakter baik yang dimiliki oleh masing-masing tetua yang berbeda genetiknya (Dewi-Hayati et al., 2017b). Teknik persilangan membutuhkan pengetahuan mengenai karakter unggul yang ingin diperbaiki, fenologi pembungaan, fase reseptif bunga betina dan fase antesis bunga jantan, serta teknik melakukan persilangan (Dewi-Hayati dan Sutoyo, 2018). Oleh karena itu tahapan pertama dari pelatihan hibridisasi adalah pengenalan terhadap setiap organ seks tanaman. Peserta dipersilakan menggunakan kaca mata pembesar khusus untuk membantu persilangan (Gambar 4).
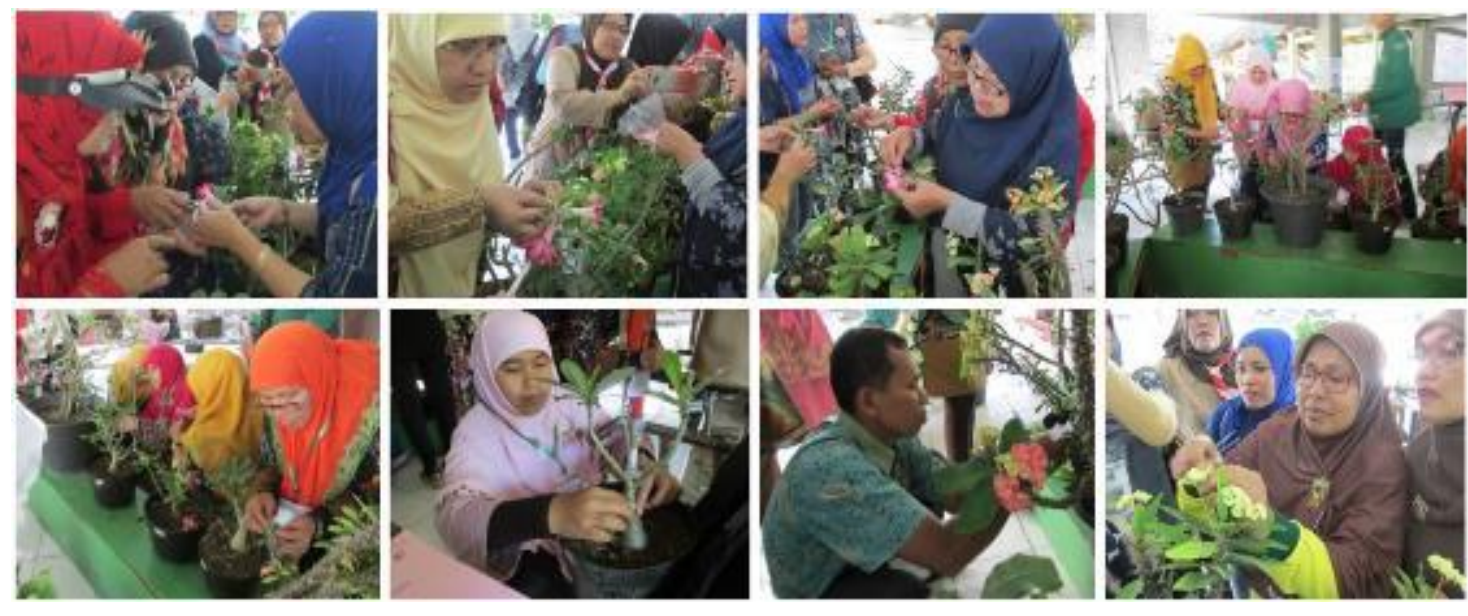

Gambar 4. Praktek langsung para guru melakukan perbanyakan tanaman dengan teknik sambung, dan persilangan

Tanaman yang sudah diperbaiki penampilannya melalui persilangan dapat diperbanyak secara vegetatif untuk mempertahankan karakter-karakter unggul yang dimilikinya. Teknik propagasi yang dilatih adalah teknik setek dan sambung. Perbedaan teknik sambung pada tanaman hias dengan jenis tanaman lainnya adalah harus tetap mempertahankan keindahan pada bekas sambungan.

Penambahan zat pengatur tumbuh (ZPT) yang didemonstrasikan pada kegiatan pelatihan adalah penggunaan auksin untuk mempercepat perakaran pada setek. Ada dua bahan auksin yang digunakan yaitu dalam bentuk pasta dan cair. Pemanfaatan ZPT yang lain adalah sebagai retardan yang dapat digunakan untuk mengatur penampilan tanaman agar lebih pendek, kompak dan berbunga lebih banyak (Sutoyo, 2017). Masing-masing peserta juga dibekali dengan Paclobutrazol, salah satu ZPT yang berperan sebagai retardan untuk dibawa pulang dan dicobakan di sekolah masing-masing. Retardan digunakan untuk memperpendek penampilan tanaman hias.

Monitoring dilaksanakan pada setiap kegiatan dengan mendata jumlah pertanyaan yang dilontarkan oleh peserta kepada nara sumber. Banyaknya pertanyaan menunjukkan besarnya tingkat keingintahuan guru. Pertanyaan yang diajukan pada setiap sesi berkisar $9-15 \%$ dari total guru yang hadir. Sesi yang paling menarik bagi guru-guru adalah sesi persilangan tanaman hias karena merupakan kegiatan yang baru pertama kali mereka lakukan.

Untuk mengevaluasi pelaksanaan kegiatan maka survei dilakukan pada akhir kegiatan. Hasil analisis Likert dari enam pertanyaan (Tabel 1) yang diajukan kepada 30 responden yang berasal dari guru dan siswa menunjukkan persentase sebesar 95.6\% (Tabel 1). Ini berarti bahwa secara umum kegiatan pengabdian masyarakat yang dilakukan sangat bermanfaat. 
Tabel 1. Hasil kuesioner guru-guru Biologi SMA se-Sumatera Barat pada pelatihan persilangan, perbanyakan tanaman dan penggunaan ZPT pada tanaman hias.

\begin{tabular}{|c|c|c|c|c|c|}
\hline \multirow{2}{*}{ Pertanyaan kuesioner } & \multicolumn{4}{|c|}{ Jumlah pilihan jawaban } & \multirow{2}{*}{$\begin{array}{l}\text { Total } \\
\text { skor }\end{array}$} \\
\hline & A & B & $\mathrm{C}$ & D & \\
\hline $\begin{array}{l}\text { Bagaimana tanggapan anda tentang pelaksanaan kegiatan } \\
\text { pengabdian masyarakat tim Faperta Unand secara umum? }\end{array}$ & 24 & 6 & 0 & 0 & 108.0 \\
\hline $\begin{array}{l}\text { Apakah kegiatan pengabdian yang dilaksanakan memiliki } \\
\text { kesesuaian dengan kebutuhan / permasalahan di sekolah? }\end{array}$ & 25 & 5 & 0 & 0 & 110.0 \\
\hline $\begin{array}{l}\text { Bagaimana manfaat yang diperoleh dari modul yang } \\
\text { diberikan? }\end{array}$ & 30 & 0 & 0 & 0 & 120.0 \\
\hline $\begin{array}{l}\text { Bagaimana manfaat yang diperoleh dari } \\
\text { penyuluhan/pemberian materi yang diberikan? }\end{array}$ & 25 & 5 & 0 & 0 & 110.0 \\
\hline $\begin{array}{l}\text { Bagaimana manfaat yang diperoleh dari pelatihan yang } \\
\text { diberikan? }\end{array}$ & 30 & 0 & 0 & 0 & 120.0 \\
\hline $\begin{array}{l}\text { Bagaimana manfaat yang diperoleh dari bahan dan } \\
\text { peralatan yang diberikan? }\end{array}$ & 30 & 0 & 0 & 0 & 120.0 \\
\hline Rata-rata skor & & & & & 114.7 \\
\hline Nilai (\%) & & & & & 95.6 \\
\hline
\end{tabular}

Data kuesioner juga menunjukkan bahwa semua guru menganggap kegiatan pengabdian masyarakat yang dilakukan berkontribusi pada keindahan sekolah. Sebanyak 93\% guru dan siswa menganggap bahwa kegiatan pengabdian masyarakat yang dilakukan berkontribusi pada kegiatan adiwiyata sekolah sedangkan 7\% menganggap kegiatan pengabdian masyarakat berkaitan dengan usaha kewirausahaan. Kegiatan yang dilakukan dianggap memberikan pengetahuan dan keterampilan, baik kepada guru maupun siswa dengan persentase sebesar $93 \%$, dan hanya $7 \%$ yang menganggap kegiatan yang dilakukan berkontribusi pada peningkatan keterampilan saja. Seluruh responden menganggap kegiatan ini perlu dilanjutkan di masa mendatang.

\section{KESIMPULAN}

Melalui kegiatan penyuluhan, demonstrasi, pelatihan dan praktek mandiri, guru-guru Biologi SMA se-Sumatera Barat dapat menerapkan dan mentransfer pengetahuan dan keterampilan yang dimilikinya mengenai pembuatan media tanam, perbanyakan dan persilangan, serta penggunaan ZPT pada tanaman hias kepada siswa. Hasil analisis Likert sebesar 95.6\% menunjukkan bahwa kegiatan pengabdian masyarakat yang dilakukan sangat bermanfaat bagi para guru MGMP Biologi se Sumatera Barat, dengan demikian kegiatan ini perlu dilanjutkan di masa mendatang. 


\section{UCAPAN TERIMA KASIH}

Penulis menyampaikan terima kasih kepada Dekan Fakultas Pertanian Universitas Andalas yang memungkinkan kegiatan ini bisa terlaksana di fakultas, dan Kemenristek DIKTI atas Hibah Ipteks bagi Masyarakat No. 04/UN.16.17/XIII.PM.IbM/LPPM/2017 sebagai penyandang dana untuk pembelian bahan dan peralatan. Ucapan yang sama juga disampaikan kepada Kepala Dinas Pendidikan Sumatera Barat serta ketua MGMP Biologi SMA Sumatera Barat; Ibu Dra. Fitri Yeni.

\section{DAFTAR PUSTAKA}

Dewi-Hayati, P.K. 2017a. Tanaman Hias Dalam Dewi-Hayati, P.K., Sutoyo, Herviyanti, Warnita, Trizelia dan Martinius. Modul Pelatihan Hibridisasi, Propagasi dan Aplikasi ZPT pada Tanaman Hias untuk Guru-Guru Biologi SMA se - Sumatera Barat. Fakultas Pertanian Universitas Andalas. 65 hal.

Dewi-Hayati, P.K. 2017b. Hibridisasi pada Tanaman Hias. Dalam Dewi-Hayati, P.K., Sutoyo, Herviyanti, Warnita, Trizelia dan Martinius. Modul Pelatihan Hibridisasi, Propagasi dan Aplikasi ZPT pada Tanaman Hias untuk Guru-Guru Biologi SMA se - Sumatera Barat. Fakultas Pertanian Universitas Andalas. 65 hal.

Dewi-Hayati, P.K., dan Sutoyo. 2018. Penuntun Praktikum Pemuliaan Hibrida. LPTIK Universitas Andalas. 40 hal.

Herviyanti. 2017. Kesuburan Tanah dan Peranan Bahan Organik pada Budidaya Tanaman Hias. Dalam Dewi-Hayati, P.K., Sutoyo, Herviyanti, Warnita, Trizelia dan Martinius. Modul Pelatihan Hibridisasi, Propagasi dan Aplikasi ZPT pada Tanaman Hias untuk Guru-Guru Biologi SMA se - Sumatera Barat. Fakultas Pertanian Universitas Andalas. 65 hal.

Martinius. 2017. Pengenalan dan Pengendalian Penyakit Tanaman Hias. Dalam Dewi-Hayati, P.K., Sutoyo, Herviyanti, Warnita, Trizelia dan Martinius. Modul Pelatihan Hibridisasi, Propagasi dan Aplikasi ZPT pada Tanaman Hias untuk Guru-Guru Biologi SMA se - Sumatera Barat. Fakultas Pertanian Universitas Andalas. 65 hal.

Rusydi, I, S. Siswanti, dan W. Laksito Y.S. 2015. Analisis efektivitas pemanfaatan multimedia pada pencitraan AMIK Amikom Cipta Darma Surakarta. Jurnal Teknologi Informasi dan Komunikasi 3(2):34-41.

Sutoyo. 2017. Zat Pengatur Tumbuh dan Aplikasinya pada Tanaman Hias. Dalam Dewi-Hayati, P.K., Sutoyo, Herviyanti, Warnita, Trizelia dan Martinius. Modul Pelatihan Hibridisasi, Propagasi dan Aplikasi ZPT pada Tanaman Hias untuk Guru-Guru Biologi SMA se - Sumatera Barat. Fakultas Pertanian Universitas Andalas. 65 hal.

Trizelia. 2017. Pengenalan dan Pengendalian Hama Tanaman Hias. Dalam Dewi-Hayati, P.K., Sutoyo, Herviyanti, Warnita, Trizelia dan Martinius. Modul Pelatihan Hibridisasi, Propagasi dan Aplikasi ZPT pada Tanaman Hias untuk Guru-Guru Biologi SMA se - Sumatera Barat. Fakultas Pertanian Universitas Andalas. 65 hal.

Warnita. 2017. Pengaturan Komposisi dan Pembuatan Media Tanam pada Pembibitan Tanaman Hias. Dalam Dewi-Hayati, P.K., Sutoyo, Herviyanti, Warnita, Trizelia dan Martinius. Modul Pelatihan Hibridisasi, Propagasi dan Aplikasi ZPT pada Tanaman Hias untuk Guru-Guru Biologi SMA se - Sumatera Barat. Fakultas Pertanian Universitas Andalas. 65 hal.

Zulkarnain. 2009. Dasar-dasar Hortikultura. Bumi Aksara. Jakarta. 